\title{
A new role for complement C3: regulation of antigen processing through an inhibitory activity
}

\author{
Villiers Christian L. ${ }^{1}$, Cretin François ${ }^{2}$, Lefebvre Nicole ${ }^{1}$, Marche Patrice N. ${ }^{1}$, Villiers Marie-Bernadette ${ }^{1 *}$ \\ 1 Institut d'oncologie/développement Albert Bonniot de Grenoble INSERM : U823, CHU Grenoble, EFS, Université Joseph Fourier - \\ Grenoble I, Institut Albert Bonniot, BP170, 38042 Grenoble Cedex 9,FR
}

2 BBSI, Biochimie et biophysique des systèmes intégrés CNRS : UMR5092, CEA : DSVIIRTSV, Université Joseph Fourier - Grenoble I, 17 Rue des martyrs 38054 GRENOBLE CEDEX 9,FR

* Correspondence should be adressed to: Marie-Bernadette Villiers <Marie-Bernadette.Villiers@ujf-grenoble.fr>

\begin{abstract}
Increasing evidence underlines the involvement of complement component $\mathrm{C} 3$ in the establishment of acquired immunity which appears to play a complex role and to act at different levels. As antigen proteolysis by antigen presenting cells is a key event in the control of antigen presentation efficiency, and consequently in the quality of the immune response, we investigated whether $\mathrm{C} 3$ could modulate this step. Our results demonstrate for the first time that $\mathbf{C 3}$ can interfere with antigen proteolysis: i) proteolysis of tetanus toxin (TT) by the lysosomal fraction from a human monocytic cell line (U937) is impaired in the presence of C3, ii) this effect is $\mathrm{C} 3$-specific and involves the $\mathrm{C} 3 \mathrm{c}$ fragment of the protein, iii) $\mathrm{C3c}$ is effective even after disulfide disruption, but none of its three constitutive peptides is individually accountable for this inhibitory effect, iv) the target protease(s) exhibit(s) a serine-protease activity. The physiological relevance of our results is demonstrated by experiments showing a subcellular colocalisation of TT and C3 after their uptake by $\mathrm{U} 937$ and the reduction of TT proteolysis once internalised together with C3.
\end{abstract}

These results highlight a novel role for $\mathrm{C} 3$ that broadens its capacity to modulate acquired immune response.

MESH Keywords Animals ; Antigen Presentation ; drug effects ; immunology ; Antigen-Presenting Cells ; drug effects ; immunology ; physiology ; Complement C3 ; immunology ; pharmacology ; physiology ; Down-Regulation ; drug effects ; immunology ; Humans ; Immunity, Cellular ; drug effects ; Lysosomes ; drug effects ; immunology ; metabolism ; Mice ; Mice, Inbred BALB C ; Protease Inhibitors ; immunology ; pharmacology ; Substrate Specificity ; Tetanus Toxin ; immunology ; metabolism ; U937 Cells

Author Keywords Complement ; C3 ; Antigen presentation ; Macrophages ; Proteolysis

\section{Introduction}

The involvement of the complement system, a key component of innate immunity, in the establishment of the adaptative immune response is now well-documented (reviewed in references (Carroll, 2004; Walport, 2001)). Among the components of the complement cascade, C3 plays a unique role, due to its different characteristics: not only is it the most abundant complement protein in serum, but it is also the meeting point of the three activation pathways of the complement cascade. Moreover, C3 belongs to the $\alpha 2$-macroglobulin ( $\alpha 2-\mathrm{M}$ ) family that contains an intrachain thioester bond (Dodds and Law, 1988). The breakdown of this bond upon activation of C3 to C3b results in a transient capacity for the molecule to form a covalent bond with nucleophilic acceptors such as amino or hydroxyl groups (Law et al., 1979; Sim et al., 1981). Finally, C3b can undergo successive rounds of cleavage leading to different fragments (iC3b, C3dg), each of them being able to interact specifically with receptors expressed by most immune cells (Villiers and Villiers, 2003; Villiers et al., 2004). These characteristics confer a variety of different properties to $\mathrm{C} 3$ and its fragments, including acting as bifunctional ligands between antigens (Ag) and cells (Villiers et al., 2003; Villiers et al., 1996; Weiss et al., 1989), as signalling effectors (Cherukuri et al., 2001; Fearon and Carter, 1995; Wagner et al., 2006), or as anaphylatoxins (Hawlisch et al., 2004; Schulman et al., 1988; Takafuji et al., 1994). The role of C3 in acquired immune response modulation has first been demonstrated "in vivo", using complement-depleted or -deficient animals ( Bottger et al., 1986; Ochs et al., 1983; Pepys, 1974). Increasing evidence from "in vivo" as well as "in vitro" experiments has raised since, revealing the complexity of this modulatory effect which operates at different levels, including cytokine release, $\mathrm{T}$ cell proliferation, regulatory $\mathrm{T}$ cell development and B cell activation/differentiation (reviewed in references (Carroll, 2004; Morgan et al., 2005; Wagner and Hansch, 2006)). The mechanisms involved are not yet fully understood and are still under investigation.

Previous work using C3b-TT complexes demonstrated the influence of C3b on Ag presentation at the cellular level. Ag recognition by $\mathrm{T}$ lymphocytes requires Ag processing by antigen presenting cell (APC), which involves limited proteolysis, loading of the antigenic peptides onto MHC-II molecules and presentation of the MHC-II - peptide complexes to the cell surface. We demonstrated previously that C3b fixation on TT results in increased Ag uptake by APC (Rey-Millet et al., 1994; Villiers et al., 1996), improved antigenic peptide binding on MHC class II molecules (Serra et al., 1997), modified intracellular trafficking (Perrin-Cocon et al., 2004; Rey-Millet et al., 1994) and delayed Ag proteolysis in subcellular compartments (Jacquier-Sarlin et al., 1995). To gain new insight into this last point, we assessed here whether $\mathrm{C} 3 \mathrm{~b}$ per se, affects the activity of lysosomal proteases involved in Ag processing, using TT as model Ag. Experiments were performed with monocytic cells (U937) as i) they have higher protease content than B cells or dendritic cells (Delamarre 
et al., 2005) and ii) they are known to secrete larger amount of C3 at sites of inflammation than other APC (Einstein et al., 1977). Our results constitute the first evidence that $\mathrm{C} 3 \mathrm{~b}$ can indeed inhibit lysosomal proteases. This inhibitory activity is specific of $\mathrm{C} 3 \mathrm{~b}$ and is supported by the $\mathrm{C} 3 \mathrm{c}$ fragment. The presence of the three $\mathrm{C} 3 \mathrm{c}$ polypeptides is required, although their disulfide linkage is not imperative. The use of known protease inhibitors suggests that the target-protease(s) of C3b belong(s) to the serine-protease family. Finally, experiments using living cells demonstrate the physiological relevance of these results.

\section{Materials and methods}

\section{Proteins}

Purified TT was generously supplied by Dr J.R. Cartier (Institut Mérieux, France) and was further purified as described previously ( Villiers et al., 1991). Trypsin (L-tosylphenylalanyl chloromethane-treated), soybean trypsin inhibitor (SBTI), ovalbumin, BSA, and hemoglobin were from Sigma Aldrich Co., St Louis, Mo., USA. Elastase was from Roche Diagnostic, Meylan, France. a2-M was a kind gift from Dr J.-J. Feige (IRTSV/APV, Grenoble, France). Immunoglobulin G2a was produced by a hybridoma derived from BALB/c.

\section{Purification of $\mathrm{C} 3$ and its fragments}

C3 was purified from outdated human citrated plasma obtained from the Etablissement Français du Sang (Grenoble, France) according to (Al Salihi et al., 1982). C3b was prepared by incubating purified $\mathrm{C} 3$ with $0.1 \%(\mathrm{w} / \mathrm{w})$ trypsin at $23^{\circ} \mathrm{C}$ for $1 \mathrm{~h}$ and the reaction was stopped by adding $0.2 \%(\mathrm{w} / \mathrm{w}) \mathrm{SBTI}$ and incubating at $37^{\circ} \mathrm{C}$ for $15 \mathrm{~min} . \mathrm{C} 3 \mathrm{c}$ and $\mathrm{C} 3 \mathrm{de}$ were obtained by incubating $\mathrm{C} 3$ with elastase $(100 / 5, \mathrm{w} / \mathrm{w})$ in PBS during $18 \mathrm{~h}$ at $37^{\circ} \mathrm{C}$. The two fragments were further purified using a Sephadex G-100 superfine $(2.6 \times 90)$ column equilibrated in $150 \mathrm{mM} \mathrm{NaCl}, 20 \mathrm{mM}$ Tris- $\mathrm{HCl}, \mathrm{pH} 7.2$, at a flow rate of $8 \mathrm{ml} / \mathrm{h}$. The three polypeptides constituting $\mathrm{C} 3 \mathrm{c}(\alpha 1$, $\alpha 2$ and $\beta$ ) were obtained after reduction of the molecule $\left(1 \mathrm{~h}\right.$ at $37^{\circ} \mathrm{C}$ in the presence of $50 \mathrm{mM}$ dithiothreitol) followed by alkylation $\left(30 \mathrm{~min}\right.$ at $37^{\circ} \mathrm{C}$ in the presence of $137 \mathrm{mM}$ iodoacetamide), and purification by reverse phase-HPLC using a Vydac C4 column (Interchim, Montluçon, France). The polypeptides were acidified using trifluoroacetic acid $0.1 \%(\mathrm{v} / \mathrm{v})$, loaded onto the column at $0.25 \mathrm{ml} / \mathrm{min}$ and eluted using a linear acetonitril gradient $(0-80 \%, \mathrm{v} / \mathrm{v})$. Absorbance was monitored at $215 \mathrm{~nm}$. The concentration of purified proteins was estimated from absorbance at $280 \mathrm{~nm}$, using E1\%, $1 \mathrm{~cm}=11.5$ for TT (Villiers et al., 1993), 9.7 for C3 and C3b (Tack and Prahl, 1976), 10.0 for C3c, 13.34 for $\mathrm{C} 3 \mathrm{de}$ and for the fragments ( $\alpha 1: 4.57, \alpha 2: 11.23$, and $\beta: 7.97)$, values were calculated using the ExPASy facilities.

\section{Protein labelling \\ Radioactivity}

Proteins were labelled with $\mathrm{Na}{ }^{125} \mathrm{I}$ using the iodogen method (Salacinski et al., 1981). ${ }^{125} \mathrm{I}(3.7 \mathrm{GBq} / \mathrm{ml})$ was from GE-Healthcare (France) and the Iodogen iodination reagent was from Pierce Chemical Co. (Interchim, Montluçon, France).

Free iodine was eliminated by filtration through a Sephadex G50-fine column (GE-Healthcare, France). Specific radioactivity was 170 $\mathrm{Bq} / \mu \mathrm{g}$.

\section{Fluorescence}

Proteins were labelled with Cy2 (TT) and Cy3 (C3) (GE-Healthcare, France) as recommended by the manufacturer.

\section{Cells and culture condition}

U937 cells (Sundström and Nilsson, 1976) were obtained from the American Type Culture Collection (Manassas, VA, USA) and maintained in culture at $0.5 \times 10^{6}$ cells/ml in RPMI-1640 (Invitrogen, France), supplemented with $2 \mathrm{mM} \mathrm{L-glutamine} \mathrm{and} 10 \%$ heat-inactivated $\left(56^{\circ} \mathrm{C}, 30 \mathrm{~min}\right)$ foetal calf serum. Cultures were routinely passaged every 3 days and cells were used $24 \mathrm{~h}$ after the last passage.

\section{Subcellular fractionation}

Cells $\left(70 \times 10^{6}\right.$ cells $/ \mathrm{ml}$ in $250 \mathrm{mM}$ sucrose, $1 \mathrm{mM}$ EDTA, $1 \mathrm{mM}$ hepes, $\mathrm{pH}$ 7.2) were disrupted and fractionated on a Percoll gradient as previously described (Villiers et al., 1996). LF was characterized as previously described (Perrin-Cocon et al., 2004) and stored at $-80^{\circ}$ C until use.

\section{Analysis of TT proteolysis \\ by lysosomal fraction}

${ }^{125} \mathrm{I}$-TT $(5 \mu \mathrm{g})$ was incubated in $50 \mathrm{mM} \mathrm{Na}$ acetate $(50 \mu \mathrm{l})$ for $18 \mathrm{~h}$ at $37^{\circ} \mathrm{C}$, in the presence of $\mathrm{LF}$ (equivalent to $2.5 \times 10^{6}$ cells) and of different proteins $(5 \mu \mathrm{g})$. The mixture was analyzed on SDS-PAGE (10-15\% acrylamide) in non reducing conditions and the radioactivity associated with the protein bands was quantified using a Phosphorimager (GE-Healthcare, France). TT proteolysis was assumed to be the reduction in the $150 \mathrm{kDa}$ band (= intact TT) radioactivity compared to the total radioactivity present on the gel. 


\section{by $U 937$ cells}

$10 \times 10^{6}$ cells were incubated at $37^{\circ} \mathrm{C}$ for different times in the presence of ${ }^{125} \mathrm{I}-\mathrm{TT}(0.1 \mathrm{mg} / \mathrm{ml})$ alone or with C3b $(0.1 \mathrm{mg} / \mathrm{ml})$. Then, cells were washed three times in PBS and disrupted using a "cell-disrupter" (1 shot- $0.75 \mathrm{~kW}$ model, Constant systems Ltd., Warwick, U.K.) with a pressure of 350 bar. Two successive centrifugations were performed first to remove intact cells and membranes (3min at

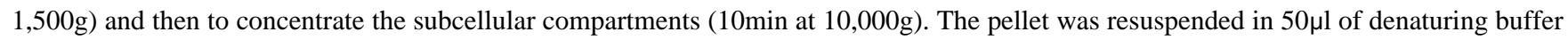
( $8 \mathrm{M}$ urea, $2 \%$ SDS, $0.2 \mathrm{M}$ tris, $\mathrm{pH} 8.0$ ) and analysed on SDS-PAGE (7.5\% acrylamide).

\section{Confocal microscopy}

Cells in $100 \mu \mathrm{l}$ culture medium $\left(10^{7} / \mathrm{ml}\right)$ were incubated in the presence of fluorescent TT and $\mathrm{C} 3 \mathrm{~b}(0.1 \mathrm{mg} / \mathrm{ml} \mathrm{each})$ at $37^{\circ} \mathrm{C}$ for $2 \mathrm{~h}$. Cells were washed three times in PBS and allowed to adhere on poly-L-lysine-coated lamellas for 40 min at room temperature. Lamellas were washed three times in PBS and cells were fixed with paraformaldehyde 3\% (w/v) in PBS, 10min at room temperature. Samples were mounted in Dako fluorescent mounting medium (Beckman Coulter, Roissy CDG, France), sealed, and stored at $4{ }^{\circ} \mathrm{C}$ in the dark. Fixed cells were imaged at room temperature using the inverted confocal and two-photon laser-scanning microscope (LSM 510 NLO, Carl Zeiss) equipped with a 40×/1.3 Plan-Neofluar oil immersion objective. The pinhole adjustment to 1 Airy unit resulted in less than $0.7 \mu \mathrm{m}$ optical slice at $488 \mathrm{~nm}$ excitation wavelength. The image plane was chosen to be near the equator of the cell body and nucleus. No significant photobleaching was induced during image acquisition in either detection channel.

\section{Results}

\section{Inhibitory effect of C3 upon tetanus toxin (TT) proteolysis by lysosomal fraction (LF)}

In order to assess whether $\mathrm{C} 3$ could affect some proteolytic processes, ${ }^{125}$ I-TT proteolysis by the LF of U937 cells was analyzed in the presence or absence of $\mathrm{C} 3$, as described in the Materials and Methods section. As shown in Fig. 1, TT is present as two close bands $\left(\mathrm{M}_{\mathrm{r}}=\right.$ 150,000 and 140,000) on SDS-PAGE under non-reducing conditions (lane 1) and is partially proteolyzed by LF (lane 2), as indicated by the appearance of three new major bands $\left(\mathrm{M}_{\mathrm{r}}=100,000,48,000\right.$ and 46,000) together with small fragments $\left(\mathrm{M}_{\mathrm{r}}<15,000\right)$ migrating with the dye front, and the parallel decrease in band intensity corresponding to intact TT. An additional, fainter, band featuring an apparent $\mathrm{M}_{\mathrm{r}}=$ 120,000 can also be detected. When C3 is added to the mixture prior to incubation of TT with LF, a similar electrophoretical pattern is observed, although the amount of non-proteolyzed TT remains higher than in the absence of C3 (lane 3): C3 does therefore not modify the proteolytic fragments generated by LF, but rather at least partially inhibits its proteolytic activity.

The inhibitory effect of $\mathrm{C} 3$ on TT proteolysis by LF was confirmed by a kinetic analysis: As shown in Fig. 2, in these conditions, only $15 \%$ of input TT is proteolyzed after a $24 \mathrm{~h}$ incubation in the presence of $\mathrm{C} 3$ against $45 \%$ in its absence.

\section{Specificity of the $\mathrm{C} 3$ inhibitory effect}

To assess the specificity of the observed $\mathrm{C} 3$ inhibitory effect, ${ }^{125} \mathrm{I}-\mathrm{TT}$ was incubated with LF in the presence of various unlabelled proteins $(\mathrm{TT}=150 \mathrm{kDa}, \mathrm{C} 3=185 \mathrm{kDa}$, ovalbumine $(\mathrm{Ova})=43 \mathrm{kDa}, \mathrm{BSA}=67 \mathrm{kDa}$, hemoglobine $(\mathrm{Hem})=68 \mathrm{kDa}, \mathrm{IgG} 2 \mathrm{a}=150 \mathrm{kDa}, \alpha 2-\mathrm{M}=4 \times$ $180 \mathrm{kDa}$ ) and its proteolysis was quantified after SDS-PAGE. An assay including only ${ }^{125} \mathrm{I}-\mathrm{TT}$ and LF was used as reference (100\% proteolysis). As shown in Fig. 3A, proteolysis is substantially inhibited only in the presence of C3; the other proteins tested, by contrast, only slightly decrease TT proteolysis by LF. Surprisingly, this is also the case of a2-M, which belongs to the same family as C3 (thioester-containing proteins). The observed inhibitory effect is therefore specific to $\mathrm{C} 3$. The mild proteolysis inhibitory effect featured by all the tested proteins with the exception of $\mathrm{C} 3$ is probably due to the fact that these molecules are all potential substrates for proteases, and therefore potential ${ }^{125}$ I-TT competitors for LF proteolysis. Therefore, in the following experiments, the reference assays will always include unlabelled TT $(5 \mu \mathrm{g})$ in order to eliminate the slight inhibition due to this phenomenon and to take in account only the effect due to C3.

\section{Identification of the $\mathrm{C} 3$ fragment involved in proteolysis inhibition}

Under physiological conditions, $\mathrm{C} 3$ undergoes successive proteolytic cleavages leading to various fragments, namely $\mathrm{C} 3 \mathrm{~b}$, which is subsequently cleaved into iC3b $\left(M_{r}=175,000\right.$ and 173000 respectively), then into C3c $\left(M_{r}=135,000\right)$ and C3de $\left(M_{r}=40,000\right)(V i l l i e r s$ and Villiers, 2003). In order to identify the $\mathrm{C} 3$ fragment involved in proteolysis inhibition, ${ }^{125}$ I-TT was incubated with LF in the presence of each of the different C3 fragments and analyzed using SDS-PAGE. As shown in Fig. 3B, TT degradation by lysosomal proteases is impaired in the presence of $\mathrm{C} 3, \mathrm{C} 3 \mathrm{~b}$ and $\mathrm{C} 3 \mathrm{c}$ fragments (40-50\% inhibition), but this effect is less significant in the presence of $\mathrm{C} 3 \mathrm{de}$ ( 80 $\%)$. Therefore, the observed proteolysis inhibitory effect of $\mathrm{C} 3$ is related to the $\mathrm{C} 3 \mathrm{c}$ fragment. As evidenced using SDS-PAGE (Fig. 4A), the $\mathrm{C} 3 \mathrm{c}$ fragment (apparent $\mathrm{M}_{\mathrm{r}}=135,000$ in non reducing conditions) is made of three disulfide-linked polypeptides: the $\mathrm{C} 3 \beta$ chain $\left(\mathrm{M}_{\mathrm{r}}=\right.$ $75,000)$ and the two $\alpha$ chain-derived polypeptides $\left(\alpha_{1}, M_{r}=40,000\right.$ and $\left.\alpha_{2}, M_{r}=27,000\right)$. We wondered whether the C3c inhibitory effect required the integrity of the molecule. To that aim, $\mathrm{C} 3 \mathrm{c}$ was further incubated with trypsin (trypsin $/ \mathrm{C} 3 \mathrm{c}=1 / 100$, w/w, $2 \mathrm{~h}$ at $37^{\circ} \mathrm{C}$ ): further cleavage of $\beta, \alpha_{1}$ and $\alpha_{2}$ was obtained, leading to three other polypeptides $\left(\beta^{*}, M_{r}=58,000, \alpha_{1}{ }^{*}, M_{r}=34,000\right.$ and $\left.\alpha_{2}{ }^{*}, M_{r}=23,000\right)$. ${ }^{125} I-T T$ 
proteolysis by LF in the presence or absence of trypsin-treated C3c was no longer inhibited by C3c after trypsin digestion (Fig. 4B), testifying to the need for the integrity of this fragment. As i) proteolytic activities are present in LF and ii) proteolyzed C3c does not retain any inhibitory effect, we investigated whether the $\mathrm{C} 3$ fragment is degraded upon incubation in the presence of LF. C3c is fairly resistant to proteolysis by lysosomal proteases $(12.5 \%$ degradation upon a $18 \mathrm{~h}$ incubation, data not shown), which is consistent with its inhibiting activity upon TT degradation by LF.

\section{Identification of the $\mathrm{C3c}$ domains involved in proteolysis inhibition}

To localize the proteolysis inhibitory activity within $C 3 \mathrm{c}$, the protein was reduced and we purified its three polypeptide constituents ( $\beta$, $\alpha_{1}$ and $\alpha_{2}$ ) using HPLC (Fig. 5A). Each polypeptide was then tested individually for its capacity to inhibit the proteolytic activity of LF. As shown in Fig. 5B, whereas reduction of $\mathrm{C} 3 \mathrm{c}$ by itself does not abolish its inhibitory effect, neither fragment is alone sufficient to impair TT proteolysis; in other words, the inhibitory effect of $\mathrm{C} 3 \mathrm{c}$, although independent of disulfide bridge integrity, cannot be attributable to only one of its three constitutive peptides.

\section{Characterisation of the protease family inhibited by $\mathrm{C3}$}

The protease(s) involved in TT proteolysis by LF was (were) characterized by incubating TT and LF in the presence of different inhibitors: DFP, EDTA, pepstatin A, iodoacetic acid. As illustrated in Fig. 6, proteolysis of TT is mainly due to DFP-sensitive protease(s) rather than metallo-, acid- or thiol-proteases, as it is affected only slightly by EDTA, pepstatin A or iodoacetic acid (7-15\% inhibition), whereas DFP strongly decreases TT proteolysis (58\%), to an extent similar to C3 (40\%). Moreover, the TT fragments which accumulate upon TT + LF incubation in the presence of DFP are similar to those observed in the presence of C3 whereas the presence of the other inhibitors leads to a different accumulation of fragments (data not shown). These results suggest that the target-protease(s) for C3 belong(s) to the serine-protease family.

\section{Colocalisation of TT and C3 upon cellular internalisation}

To determine if our observations made in a cell free system are physiologically relevant, we have first analysed the localisation of TT and $\mathrm{C} 3 \mathrm{~b}$ after their uptake by living cells ( $\mathrm{C} 3 \mathrm{~b}$ was used instead of $\mathrm{C} 3$ in order to allow $\mathrm{C} 3 \mathrm{~b}$ internalisation via complement receptors). To do so, U937 were allowed to internalise Cy2- TT and $\mathrm{Cy} 3-\mathrm{C} 3 \mathrm{~b}$ at $37^{\circ} \mathrm{C}$ before being examined by confocal microscopy. As it can be seen in Fig. 7, some intracellular compartments contain only $\mathrm{C} 3 \mathrm{~b}$. On the contrary and although TT is less efficiently internalised, it always colocalise with $\mathrm{C} 3 \mathrm{~b}$ as there is always an overlapping of green with red signals (yellow in merged images). One observes this phenomenon whatever the duration of the incubation, from $20 \mathrm{~min}$ to $2 \mathrm{~h}$.

\section{Inhibitory effect of C3 upon TT proteolysis in U937}

As we demonstrated the inhibitory activity of C3 upon TT proteolysis by LF and the colocalisation of these two proteins after U937 internalisation, we wondered whether $\mathrm{C} 3$ could also influence TT proteolysis in living cells. After allowing U937 to internalise ${ }^{125}$ I-TT alone or with $\mathrm{C} 3 \mathrm{~b}$ for different times at $37^{\circ} \mathrm{C}$, we analysed TT proteolysis on SDS-PAGE. The quantification of the peak corresponding to intact TT indicates that $\mathrm{C} 3 \mathrm{~b}$ interferes with intracellular proteolytic activities in living cells as the amount of unproteolysed TT is doubled in presence of $\mathrm{C} 3 \mathrm{~b}$, at least during the first 40min after internalisation (Fig. 8).

\section{Discussion}

The influence of complement component C3 on Ag presentation has been highlighted since several years. Indeed, it has been demonstrated that $\mathrm{C} 3 \mathrm{~b}$ modulates Ag processing and presentation by different APC upon covalent binding to Ag (Jacquier-Sarlin et al., 1995; Rey-Millet et al., 1994). Using macrophages from C3-deficient mice, Zhou et al. (Zhou et al., 2006) have presented evidence that C3 also modulates the potency of APC to stimulate the T-cell response, suggesting a potential effect of free C3 on immune reponse. As peptide generation through $\mathrm{Ag}$ degradation is a key event for both Ag presentation and $\mathrm{T}$ cell stimulation, we wondered whether free $\mathrm{C} 3$ could modulate Ag proteolysis in APC. To be able to correlate our present work with previous ones, we used the same Ag model (TT).

Our results demonstrate that proteolysis of TT by the LF from a human monocytic cell line (U937) was impaired by C3. This effect was quite specific of $\mathrm{C} 3$, as $\mathrm{\alpha} 2-\mathrm{M}$, another protease inhibitor belonging to the same intramolecular thioester bond-containing family ( Armstrong and Quigley, 1999), did not affect TT proteolysis. The specificity of C3 inhibitory effect is strengthened by the fact that all other proteins tested were without effect although they are added at same or greater number of molecules compared to C3, depending on their MW. We further identified C3c as being responsible for inhibiting TT proteolysis by LF. It is noteworthy that C3c retained its proteolysis inhibitory activity even after disulfide disruption, although neither of its three constitutive peptides could individually be accountable for it. This observation could be related to the intrinsic structure of $\mathrm{C} 3 \mathrm{c}$ : $\mathrm{C} 3 \mathrm{c}$ consists of several domains, one of which is formed by parts of both the $\beta$ - and $\alpha$-chains (Janssen et al., 2005). This $\beta / \alpha$ intertwined domain, which is not stabilized by a disulfide 
bridge and is thereby preserved even after reduction of the molecule, which is confirmed by the impossibility of separating the three polypeptides by gel filtration at neutral $\mathrm{pH}$ (data not shown). Thus, it is likely that this $\beta / \alpha$ intertwined domain could be involved in the observed inhibitory effect of C3c.

Previous studies have illustrated the role of C3 in Ag presentation (Jacquier-Sarlin et al., 1995; Rey-Millet et al., 1994; Santoro et al., 1994), and particularly in Ag degradation: indeed, Jacquier-Sarlin et al. reported limited TT proteolysis by B cells in the presence of C3b ( Jacquier-Sarlin et al., 1995). Furthermore, antigenic peptides production and loading on MHC II molecules are modified upon covalent binding of C3b to the Ag (Cretin et al., 2007; Serra et al., 1997). It has been shown that the TT-C3b interaction is fairly stable in endosomes, whereas it is gradually disrupted in lysosomes (Rey-Millet et al., 1994). Moreover, LF contains proteolytic activities leading to the generation of C3c-like fragments (Rey-Millet et al., 1993). These results, together with our present work, enable us to suggest a mechanism by which $\mathrm{C} 3 \mathrm{~b}$ binding to Ag may modulate Ag presentation: after their uptake by APC, Ag-C3b complexes are delivered to lysosomes, where $\mathrm{C} 3 \mathrm{c}$ fragments are generated upon lysosomal proteolytic activities. These fragments then interfere with the lysosomal proteases and at least partially inhibit their activity.

This hypothesis is strengthened by our experiments using living cells. First, analysis by confocal microscopy of U937 having internalised TT and C3 showed that C3 is always found in subcellular compartments containing TT, which makes possible their interaction. The great efficiency of C3 uptake compared to TT is probably due to the presence of C3 receptors at the surface of U937 (CD11b, CD11c, (Lopez-Rodriguez and Corbi, 1997)). Thus, whereas TT is internalised only via pinocytosis and phagocytosis, C3 could enter the cells using both receptor -independent (colocalisation with TT) and receptor-dependent pathway which may lead in this case to a different subcellular localisation (C3 alone) as shown previously on B cells (Perrin-Cocon et al., 2004). Second, the analysis of the intracellular proteolysis of TT by living APC such as U937 demonstrates that C3 is able to exert its inhibitory effect in physiological conditions. This effect decreases with time, but persists at least during the first hour after internalisation. It has been demonstrated that modulation of Ag proteolysis may interferes with Ag presentation, either by increasing or by decreasing production of antigenic peptides suitable for MHC binding (Delamarre et al., 2006; Polla et al., 2007).

The proteases involved in Ag degradation and the mechanisms that control their activities are not yet fully understood and differ according to the Ag and the cells involved (Burster et al., 2005). Cathepsins are often associated with Ag proteolysis (Hewitt et al., 1997; Hsieh et al., 2002; Ruckrich et al., 2006; Shi et al., 1999), but other proteases such as asparagine endopeptidase (AEP) also play an important role (Manoury et al., 1998). In our hands, C3c inhibited TT proteolysis in a way similar to DFP, indicating that the target protease(s) belongs to the serine-protease family; this conclusion is strengthened by the fact that all other protease inhibitors tested had less effect on TT proteolysis. A previous study by Rey-Millet et al. (Rey-Millet et al., 1993) pointed out the presence of a serine-protease activity within LF, but its involvement in Ag processing had not been established. Most attempts to identify the proteases accounting for intracellular Ag proteolysis are usually indirect, consisting in the analysis of Ag presentation to $\mathrm{T}$ cells in the presence of different inhibitors. Ag degradation has either a creative or a destructive effect, mainly depending on MHC restriction (Puri and Factorovich, 1988; Takahashi et al., 1989). Nevertheless, inhibition of Ag degradation is often related to increased Ag presentation, as demonstrated using protease inhibitors (Vidard et al., 1991), antigen resistant to degradation (Delamarre et al., 2006) or modulation of intravacuolar pH ( Savina et al., 2006). Indeed, reduced intracellular proteolysis avoids the destruction of $\mathrm{T}$ cell epitopes, favoring the production of peptide-MHC classs II complexes. This is particularly important in cells such as macrophages which possess elevated degradation capacity due to their high protease content. Here, we provide direct evidence for the control of Ag proteolysis by C3c, which could be related to the previously described C3-mediated enhancement of Ag presentation and, more generally, of the establishment of a specific immune response. C3 is therefore directly involved in Ag degradation by APC through at least two distinct mechanisms: i) C3b modulates Ag trafficking within the APC (Perrin-Cocon et al., 2004) thereby potentially affecting Ag processing through modified protease activities located within the intracellular compartments, and ii) C3 directly inhibits Ag proteolysis by lysosomal proteases, as illustrated by our results. The $\mathrm{C} 3$ present in APC could be of extracellular origin, via C3b binding to exogenous Ag, as well as of intracellular origin, since C3 is synthesized by various APC such as dendritic cells (Peng et al., 2006) or macrophages (Fischer et al., 1998). Whether endogenous C3 could influence Ag proteolysis in the same way as exogenous C3 or not remains to be established. Nevertheless, the relevance of the role of C3 in Ag presentation "in vivo" has been highlighted by Zhou et al.(Zhou et al., 2006), who demonstrated that stimulation of alloreactive $\mathrm{T}$ cells is impaired in $\mathrm{C} 3$-deficient mice.

The capacity of $\mathrm{C} 3 \mathrm{c}$ to control lysosomal degradation could provide an explanation as to why induction of an increased Ab response in mice requires injection of three C3d molecules bound to Ag (Dempsey et al., 1996) versus a single molecule of C3b (Villiers et al., 1999). Indeed, only $\mathrm{C} 3 \mathrm{~b}$ allows local production of $\mathrm{C} 3 \mathrm{c}$ which could control Ag proteolysis favouring $\mathrm{Ag}$ presentation, while Ag uptake can be ensured by both $\mathrm{C} 3 \mathrm{~b}$ and $\mathrm{C} 3 \mathrm{~d}$.

In conclusion, our results, by revealing a novel role for $\mathrm{C} 3$, supplement the integrative view on the modulatory role of $\mathrm{C} 3$ in acquired immune response, and especially on Ag processing: C3 acts at different levels such as Ag uptake (Villiers et al., 1996), intracellular Ag 
trafficking and targeting (Perrin-Cocon et al., 2004), proteolytic machinery of Ag processing (these results), Ag peptide editing (Cretin et al., 2007) and loading on MHC II molecules (Serra et al., 1997), all of these increasing Ag presentation efficiency (Jacquier-Sarlin et al., 1995) and thus the quality of the acquired immune response (Dempsey et al., 1996; Villiers et al., 1999).

\section{Abbreviations}

a2-M: alpha2-macroglobulin

Ag: antigen

DFP: di-isopropyl fluorophosphate

LF: lysosomal fraction

SBTI: soybean trypsin inhibitor

TT: tetanus toxin

\section{References:}

- Al Salihi A, Ripoche J , Pruvost L, Fontaine M 1982; Purification of complement components by hydrophobic affinity chromatography on phenyl-sepharose: purification of human C5. FEBS Lett. 150: 238- 242

- Armstrong PB , Quigley JP 1999; Alpha2-macroglobulin: an evolutionarily conserved arm of the innate immune system. Dev Comp Immunol. 23: 375 - 390

- Bottger EC, Metzger S , Bitter-Suermann D , Stevenson G, Kleindienst S, Burger R 1986; Impaired humoral immune response in complement C3-deficient guinea pigs: absence of secondary antibody response. Eur J Immunol. 16: 1231- 1235

- Burster T, Beck A, Tolosa E, Schnorrer P, Weissert R, Reich M, Kraus M, Kalbacher H, Haring HU, Weber E, Overkleeft H, Driessen C 2005; Differential processing of autoantigens in lysosomes from human monocyte-derived and peripheral blood dendritic cells. J Immunol. 175: 5940- 5949

- Carroll MC 2004; The complement system in regulation of adaptive immunity. Nat Immunol. 5: 981- 986

- Cherukuri A, Cheng PC, Sohn HW , Pierce SK 2001; The CD19/CD21 complex functions to prolong B cell antigen receptor signaling from lipid rafts. Immunity. 14: 169179

- Cretin FC, Serra VA, Villiers MB , Laharie AM, Marche PN, Gabert FM 2007; C3b complexation diversifies naturally processed T cell epitopes. Mol Immunol. 44: 28932899

- Delamarre L, Couture R, Mellman I , Trombetta ES 2006; Enhancing immunogenicity by limiting susceptibility to lysosomal proteolysis. J Exp Med. 203: 2049- 2055

- Delamarre L, Pack M , Chang H , Mellman I, Trombetta ES 2005; Differential lysosomal proteolysis in antigen-presenting cells determines antigen fate. Science. 307: 16301634

- Dempsey PW , Allison ME, Akkaraju S, Goodnow CC , Fearon DT 1996; C3d of complement as a molecular adjuvant: bridging innate and acquired immunity. Science. 271: 348- 350

- Dodds AW, Law SK 1988; Structural basis of the binding specificity of the thioester-containing proteins, C4, C3 and alpha-2-macroglobulin. Complement. 5: 89- 97

- Einstein LP, Hansen PJ , Ballow M, Davis AE 3rd, Davis JSt, Alper CA, Rosen FS, Colten HR 1977; Biosynthesis of the third component of complement (C3) in vitro by monocytes from both normal and homozygous C3-deficient humans. J Clin Invest. 60: 963- 969

- Fearon DT , Carter RH 1995; The CD19/CR2/TAPA-1 complex of B lymphocytes: linking natural to acquired immunity. Annu Rev Immunol. 13: 127- 149

- Fischer MB , Ma M, Hsu NC , Carroll MC 1998; Local synthesis of C3 within the splenic lymphoid compartment can reconstitute the impaired immune response in C3-deficient mice. J Immunol. 160: 2619- 2625

- Hawlisch H, Wills-Karp M, Karp CL, Kohl J 2004; The anaphylatoxins bridge innate and adaptive immune responses in allergic asthma. Mol Immunol. 41: 123- 131

- Hewitt EW , Treumann A, Morrice N, Tatnell PJ , Kay J, Watts C 1997; Natural processing sites for human cathepsin E and cathepsin D in tetanus toxin: implications for T cell epitope generation. J Immunol. 159: 4693- 4699

- Hsieh CS , deRoos P, Honey K, Beers C , Rudensky AY 2002; A role for cathepsin L and cathepsin S in peptide generation for MHC class II presentation. J Immunol. 168: 2618- 2625

- Jacquier-Sarlin MR, Gabert FM, Villiers MB , Colomb MG 1995; Modulation of antigen processing and presentation by covalently linked complement C3b fragment. Immunology. 84: 164- 170

- Janssen BJ , Huizinga EG, Raaijmakers HC, Roos A, Daha MR , Nilsson-Ekdahl K, Nilsson B , Gros P 2005; Structures of complement component C3 provide insights into the function and evolution of immunity. Nature. 437: 505- 511

- Law SK , Lichtenberg NA , Levine RP 1979; Evidence for an ester linkage between the labile binding site of C3b and receptive surfaces. J Immunol. 123: 1388- 1394

- Lopez-Rodriguez C, Corbi AL 1997; PU.1 negatively regulates the CD11c integrin gene promoter through recognition of the major transcriptional start site. Eur J Immunol. 27: $1843-1847$

- Manoury B , Hewitt EW , Morrice N , Dando PM , Barrett AJ , Watts C 1998; An asparaginyl endopeptidase processes a microbial antigen for class II MHC presentation. Nature. 396: 695- 699

- Morgan BP , Marchbank KJ , Longhi MP, Harris CL, Gallimore AM 2005; Complement: central to innate immunity and bridging to adaptive responses. Immunol Lett. 97: 171- 179

- Ochs HD , Wedgwood RJ , Frank MM , Heller SR , Hosea SW 1983; The role of complement in the induction of antibody responses. Clin Exp Immunol. 53: 208- 216

- Peng Q, Li K, Patel H , Sacks SH , Zhou W 2006; Dendritic cell synthesis of C3 is required for full T cell activation and development of a Th1 phenotype. J Immunol. 176: 3330- 3341

- Pepys MB 1974; Role of complement in induction of antibody production in vivo. Effect of cobra factor and other C3-reactive agents on thymus-dependent and thymus-independent antibody responses. J Exp Med. 140: 126- 145

- Perrin-Cocon LA, Villiers CL, Salamero J , Gabert F, Marche PN 2004; B cell receptors and complement receptors target the antigen to distinct intracellular compartments. J Immunol. 172: 3564- 3572

- Polla BS , Gabert F , Peyrusse BM , Jacquier-Sarlin MR 2007; Increased proteolysis of diphtheria toxin by human monocytes after heat shock: a subsidiary role for heat-shock protein 70 in antigen processing. Immunology. 120: 230- 241

- Puri J , Factorovich Y 1988; Selective inhibition of antigen presentation to cloned T cells by protease inhibitors. J Immunol. 141: $3313-3317$

- Rey-Millet CA , Chesne S , Colomb MG 1993; Associated complement C3b. Towards an understanding of its intracellular modifications. Mol Immunol. 30: 855- 864

- Rey-Millet CA, Villiers CL, Gabert FM, Chesne S, Colomb MG 1994; C3b covalently associated to tetanus toxin modulates TT processing and presentation by U937 cells. Mol Immunol. 31: 1321- 1327

- Ruckrich T , Brandenburg J , Cansier A, Muller M, Stevanovic S, Schilling K, Wiederanders B, Beck A, Melms A, Reich M , Driessen C, Kalbacher H 2006; Specificity of human cathepsin S determined by processing of peptide substrates and MHC class II-associated invariant chain. Biol Chem. 387: $1503-1511$

- Salacinski PRP, McLean C , Sykes JEC, Clement-Jones VV , Lowry PJ 1981; Iodination of proteins, glycoproteins and peptides using a solid phase oxidising agent, 1,3,4,6tetrachloro-3,6 diphenyl glycoluril (Iodogen). Anal Biochem. 117: 136- 146

- Santoro L, Drouet C, Reboul A, Mach JP, Colomb MG 1994; Covalent binding of C3b to monoclonal antibodies selectively up-regulates heavy chain epitope recognition by T cells. Eur J Immunol. 24: 1620- 1626 
- Savina A, Jancic C, Hugues S, Guermonprez P, Vargas P, Moura IC, Lennon-Dumenil AM , Seabra MC, Raposo G, Amigorena S 2006; NOX2 controls phagosomal pH to regulate antigen processing during crosspresentation by dendritic cells. Cell. 126: 205- 218

- Schulman ES, Post TJ , Henson PM, Giclas PC 1988; Differential effects of the complement peptides, C5a and C5a des Arg on human basophil and lung mast cell histamine release. J Clin Invest. 81: 918- 923

- Serra VA, Cretin F, Pepin E, Gabert FM , Marche PN 1997; Complement C3b fragment covalently linked to tetanus toxin increases lysosomal sodium dodecyl sulfate-stable HLA-DR dimer production. Eur J Immunol. 27: 2673- 2679

- Shi GP , Villadangos JA, Dranoff G, Small C , Gu L , Haley KJ , Riese R , Ploegh HL , Chapman HA 1999; Cathepsin S required for normal MHC class II peptide loading and germinal center development. Immunity. 10: 197- 206

- Sim RB , Twose TM , Paterson DS , Sim E 1981; The covalent-binding reaction of complement component C3. Biochem J. 193: 115- 127

- Sundström G, Nilsson K 1976; Establishment and characterization of a human histiocytic cell-line (U937). Int J Cancer. 17: $565-577$

- Tack BD , Prahl JW 1976; Third component of human complement: purification from plasma and physicochemical characterization. Biochemistry. 15: $4513-4521$

- Takafuji S , Tadokoro K , Ito K , Dahinden CA 1994; Degranulation from human eosinophils stimulated with C3a and C5a. Int Arch Allergy Immunol. 104: (Suppl 1) 27- 29

- Takahashi H , Cease KB , Berzofsky JA 1989; Identification of proteases that process distinct epitopes on the same protein. J Immunol. 142: 2221 - 2229

- Vidard L, Rock KL, Benacerraf B 1991; The generation of immunogenic peptides can be selectively increased or decreased by proteolytic enzyme inhibitors. J Immunol. 147 : 1786- 1791

- Villiers CL, Villiers MB 2003; Modifications of the properties of C3 complement protein after proteolytic cleavage. Recent Res Devel Biochem. 4: 685- 696

- Villiers MB , Gabert FM , Jacquier MR , Villiers CL, Colomb MG 1993; Involvement of the Zn-binding region of tetanus toxin in B and T recognition. Influence of Zn fixation. Mol Immunol. 30: 129- 136

- Villiers MB , Marche PN, Villiers CL 2003; Improvement of long-lasting response and antibody affinity by the complexation of antigen with complement C3b. Int Immunol. 15: $91-95$

- Villiers MB , Perrin-Cocon L, Marche PN , Villiers CL 2004; Complement receptors and B lymphocytes. Crit Rev Immunol. 24: 465- 478

- Villiers MB , Villiers CL , Jacquier-Sarlin MR , Gabert FM , Journet AM , Colomb MG 1996; Covalent binding of C3b to tetanus toxin: influence on uptake/internalization of antigen by antigen-specific and non-specific B cells. Immunology. 89: 348- 355

- Villiers MB , Villiers CL , Laharie AM , Marche PN 1999; Amplification of the antibody response by C3b complexed to antigen through an ester link. J Immunol. 162: 36473652

- Villiers MB , Villiers CL, Wright JF, Maison CM, Colomb MG 1991; Formation of covalent C3b-tetanus toxin complexes: a tool for the in vitro study of antigen presentation. Scand J Immunol. 34: 585- 595

- Wagner C , Hansch GM 2006; Receptors for complement C3 on T-lymphocytes: relics of evolution or functional molecules?. Mol Immunol. 43: 22- 30

- Wagner C , Ochmann C, Schoels M , Giese T, Stegmaier S , Richter R, Hug F , Hansch GM 2006; The complement receptor 1, CR1 (CD35), mediates inhibitory signals in human T-lymphocytes. Mol Immunol. 43: 643- 651

- Walport MJ 2001; Complement. Second of two parts. N Engl J Med. 344: 1140- 1144

- Weiss L , Fischer E, Haeffner-Cavaillon N, Jouvin MH , Appay MD , Bariety J , Kazatchkine M 1989; The human C3b receptor (CR1). Adv Nephrol Necker Hosp. 18: 249269

- Zhou W , Patel H , Li K, Peng Q, Villiers MB , Sacks SH 2006; Macrophages from C3- deficient mice have impaired potency to stimulate alloreactive T cells. Blood. 107: 2461- 2469

Fig. 1

TT proteolysis by LF. ${ }^{125} \mathrm{I}-\mathrm{TT}(5 \mu \mathrm{g})$ was incubated for $18 \mathrm{~h}$ at $37^{\circ} \mathrm{C}$ in the presence or absence of LF from U937 cells $\left(2.5 \times 10^{6}\right.$ cells $)$ and of C3 $(5 \mu \mathrm{g})$. The mixture was analyzed by SDS-PAGE under non reducing conditions (A). The radioactivity associated with the protein bands was quantified using a phosphorimager (B).

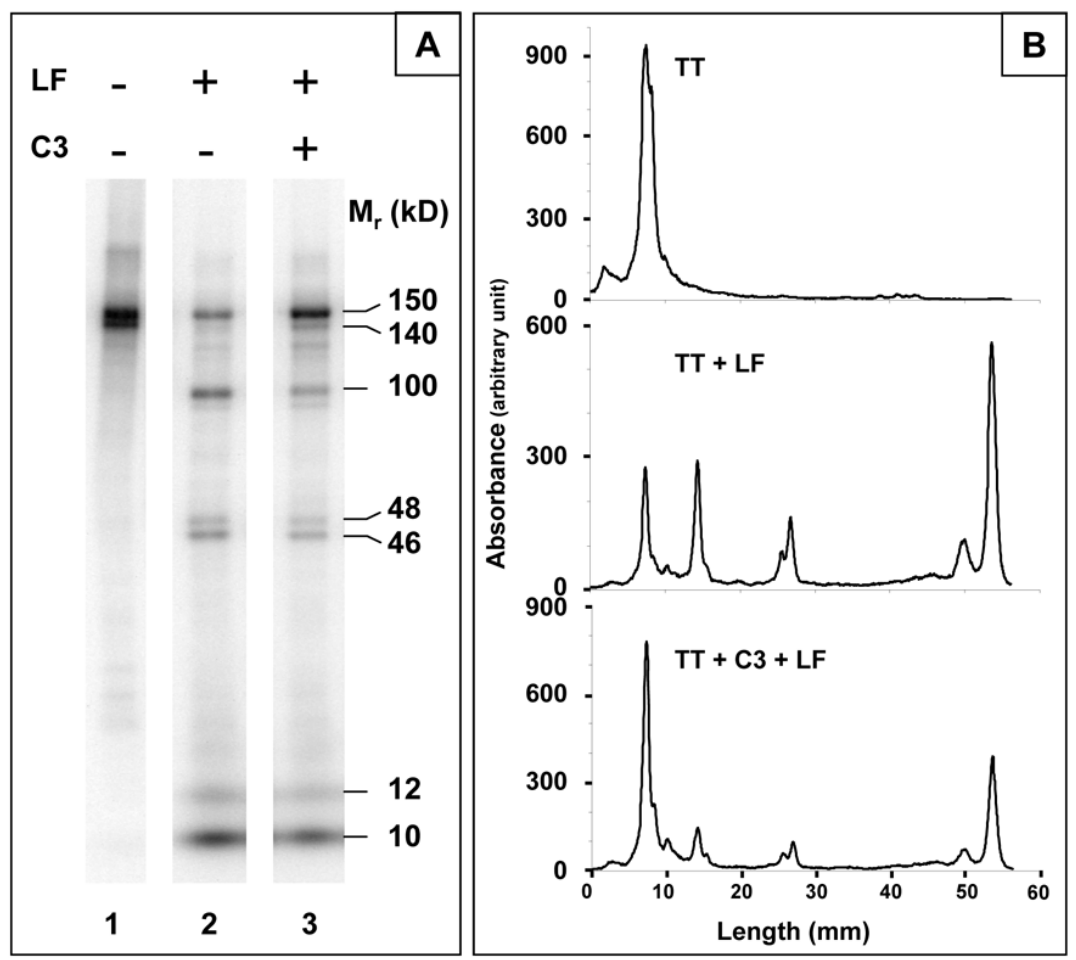


Fig. 2

Kinetic analysis of TT proteolysis by LF in the presence or absence of C3. ${ }^{125} \mathrm{I}-\mathrm{TT}(5 \mu \mathrm{g})$ was incubated at $37^{\circ} \mathrm{C}$ for different times in the presence of LF from U937 cells $\left(2.5 \times 10^{6}\right.$ cells $)$ and of C3 $(5 \mu \mathrm{g})$. TT proteolysis was analyzed by SDS-PAGE and quantified as described in Materials and Methods. Results are given as means \pm SD from at least three separate experiments.

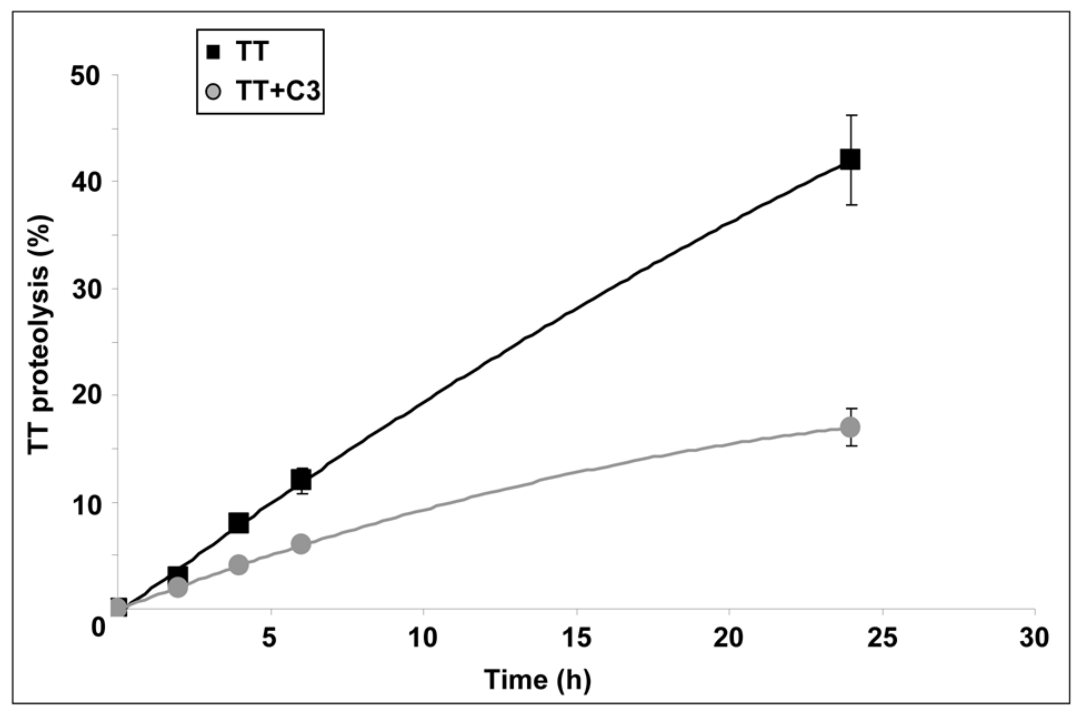

Fig. 3

Specificity of the $\mathrm{C} 3$ inhibitory effect and identification of the $\mathrm{C} 3$ fragments involved. ${ }^{125} \mathrm{I}-\mathrm{TT}(5 \mu \mathrm{g})$ was incubated for $18 \mathrm{~h}$ at $37^{\circ} \mathrm{C}$ in the presence of LF from U937 cells ( $2.5 \times 10^{6}$ cells) and of $5 \mu \mathrm{g}$ of various proteins: A) TT, C3, ovalbumine (Ova), BSA, hemoglobine (Hem), $\mathrm{IgG} 2 \mathrm{a}$, $\alpha 2-\mathrm{M}$ and B) $\mathrm{C} 3$ fragments. ${ }^{125} \mathrm{I}-\mathrm{TT}$ proteolysis was analyzed by SDS-PAGE and quantified as described in Materials and Methods. (A) $100 \%$ proteolysis was determined using an assay including only ${ }^{125} \mathrm{I}-\mathrm{TT}+\mathrm{LF}(\mathrm{Ctl})$. (B) $100 \%$ proteolysis was determined using an assay including ${ }^{125} \mathrm{I}-\mathrm{TT}+\mathrm{LF}$ and unlabelled TT $(\mathrm{Ctl})$. Results are given as means $\pm \mathrm{SD}$ from at least three separate experiments.
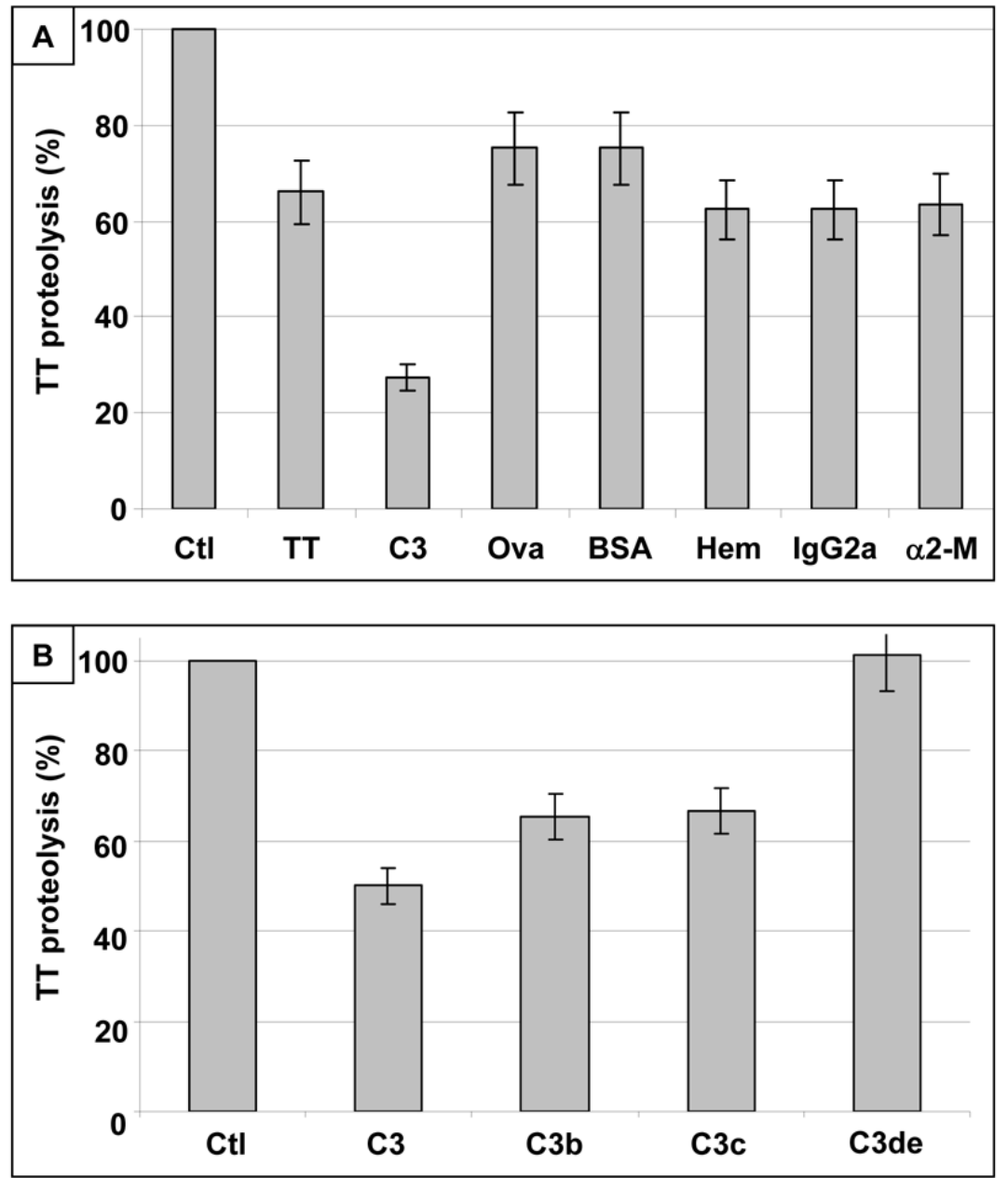
Fig. 4

Loss of the C3 inhibitory effect after C3c cleavage. (A) SDS-PAGE analysis of C3c (5 $\mu \mathrm{g}$ ) in non reducing (NR) and reducing (R) conditions before and after cleavage by trypsin (see Materials and Methods). (B) TT proteolysis by LF in the presence of intact or trypsin-proteolyzed C3c. ${ }^{125} \mathrm{I}$-TT $(5 \mu \mathrm{g})$ was incubated for $18 \mathrm{~h}$ at $37^{\circ} \mathrm{C}$ in the presence of LF from U937 cells $\left(2.5 \times 10^{6}\right.$ cells $)$ and $\mathrm{C} 3 \mathrm{c}(5 \mu \mathrm{g})$ treated or not by trypsin. TT proteolysis was analyzed by SDS-PAGE and quantified as described in Materials and Methods. $100 \%$ proteolysis was determined using an assay including ${ }^{125} \mathrm{I}-\mathrm{TT}+\mathrm{LF}$ and unlabelled TT. Results are given as means \pm SD from at least three separate experiments.
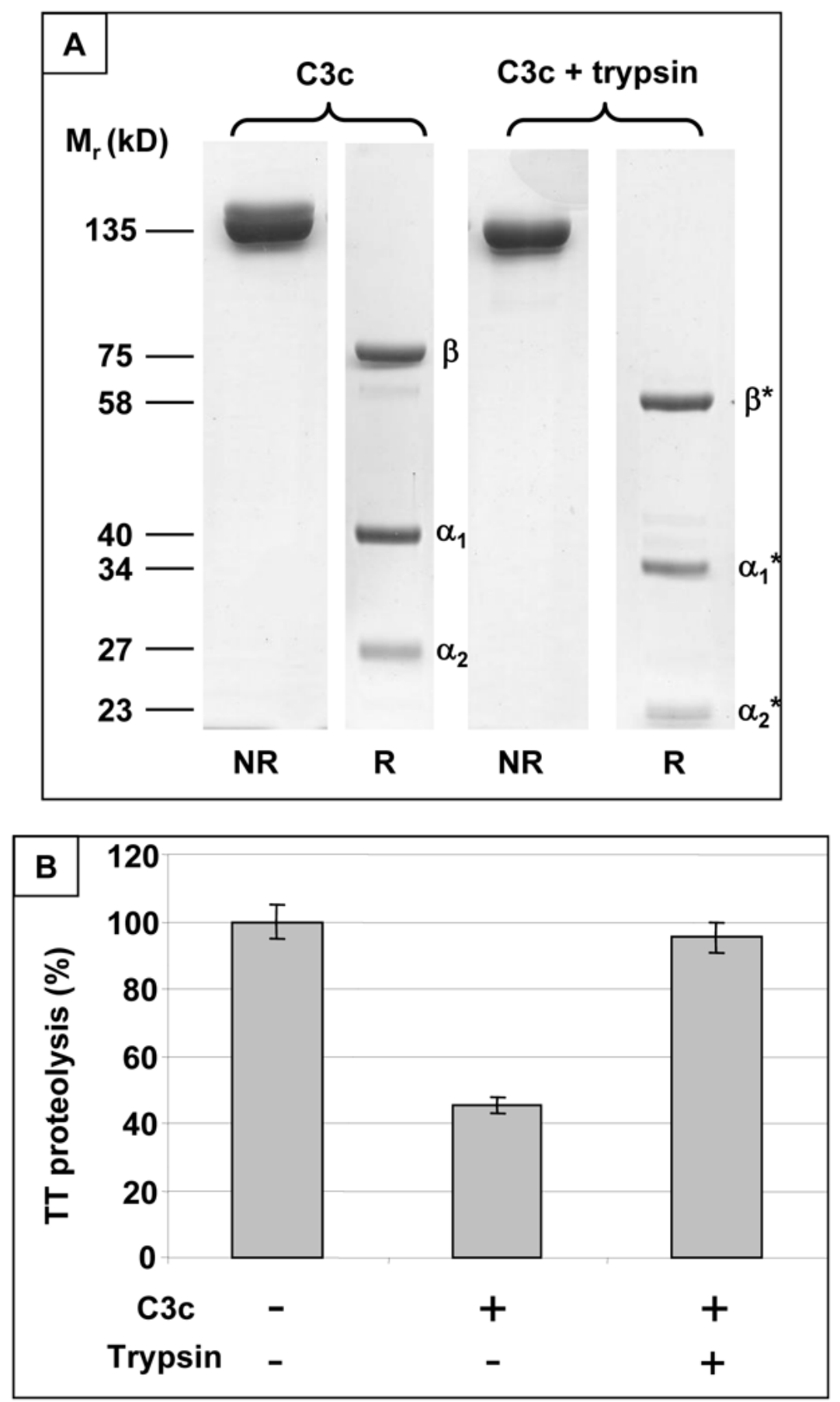
Fig. 5

Identification of $\mathrm{C} 3 \mathrm{c}$ domains involved in proteolysis inhibition. After reduction and alkylation of $\mathrm{C} 3 \mathrm{c}$, the different polypeptides were purified by reverse phase-HPLC on a Vydac C4 column (see Materials and Methods). (A) Elution profile. (B) TT proteolysis by LF in the presence of reduced or non reduced $\mathrm{C} 3 \mathrm{c}$ or each of its constitutive peptides. ${ }^{125} \mathrm{I}-\mathrm{TT}(5 \mu \mathrm{g})$ was incubated for $18 \mathrm{~h}$ at $37^{\circ} \mathrm{C}$ in the presence of LF from U937 cells $\left(2.5 \times 10^{6}\right.$ cells $)$ and C3c or its peptides $(5 \mu \mathrm{g})$. TT proteolysis was analyzed by SDS-PAGE and quantified as described in Materials and Methods. $100 \%$ proteolysis was determined using an assay including ${ }^{125} \mathrm{I}-\mathrm{TT}+\mathrm{LF}$ and unlabelled TT (Ctl). Results are given as means \pm SD from at least three separate experiments.
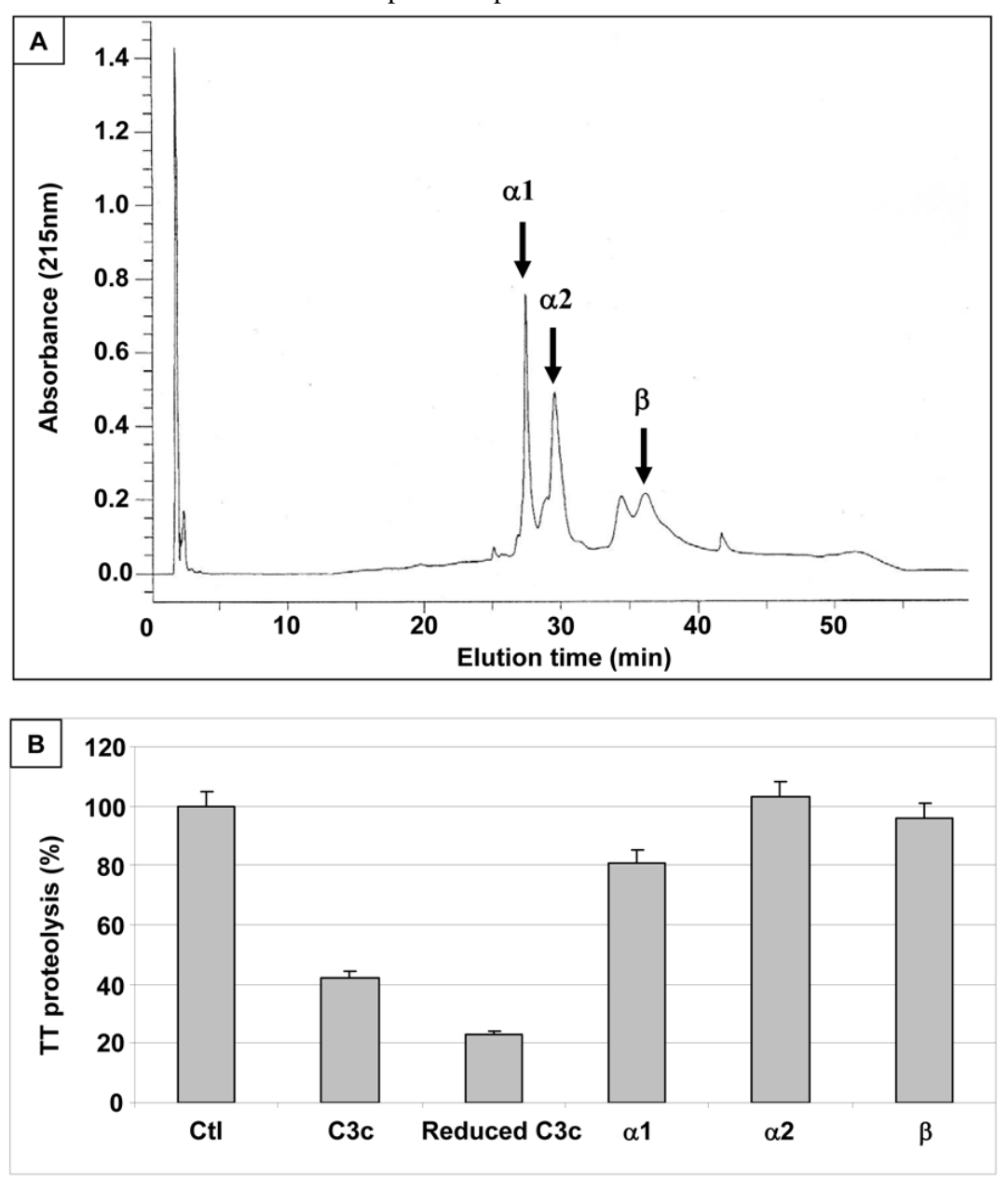

Fig. 6

Characterization of the lysosomal protease family involved in TT proteolysis. ${ }^{125} \mathrm{I}-\mathrm{TT}(5 \mu \mathrm{g})$ was incubated for $18 \mathrm{~h}$ at $37^{\circ} \mathrm{C}$ in the presence of LF from U937 cells $\left(2.5 \times 10^{6}\right.$ cells $)$ and C3 $(5 \mu \mathrm{g})$ or different protease inhibitors (DFP, EDTA, iodoacetic acid $(5 \mathrm{mM})$ or pepstatin A $(1.5 \mu$ M)). TT proteolysis was analyzed by SDS-PAGE and quantified as described in Materials and Methods. $100 \%$ proteolysis was determined using an assay including ${ }^{125} \mathrm{I}-\mathrm{TT}+\mathrm{LF}$ and unlabelled TT $(\mathrm{Ctl})$. Results are given as means $\pm \mathrm{SD}$ from at least three separate experiments.

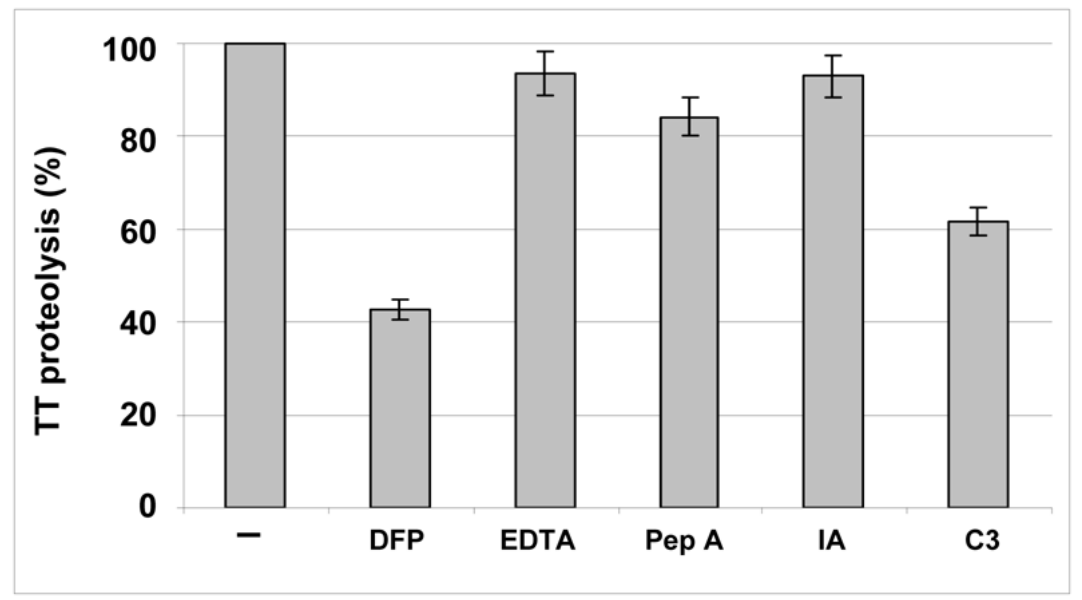


Fig. 7

Localisation of internalised TT and $\mathrm{C} 3 \mathrm{~b}$ by confocal microscopy. U937 were incubated at $37^{\circ} \mathrm{C}$ for $2 \mathrm{~h}$ in the presence of $\mathrm{Cy} 3-\mathrm{C} 3 \mathrm{~b}$ and Cy2-TT. Merged images of red (C3b) and green (TT) fluorescence are shown.

C3
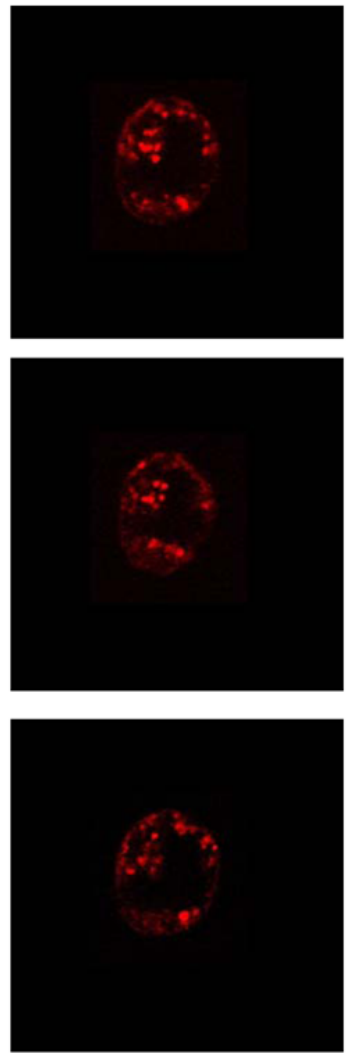

Merge
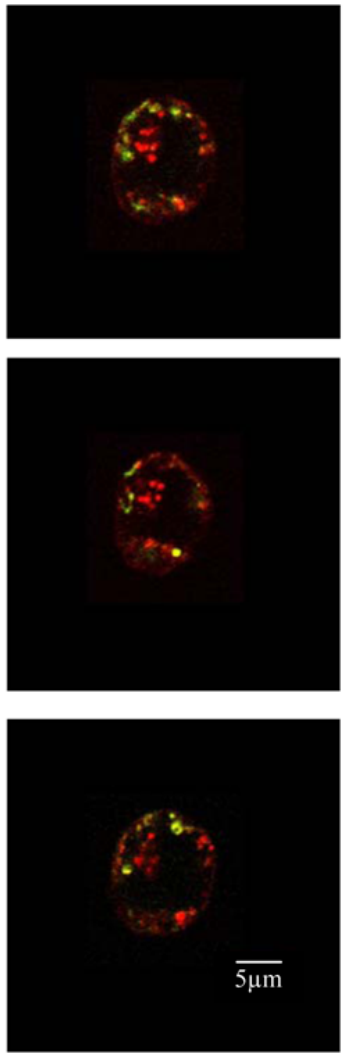

TT
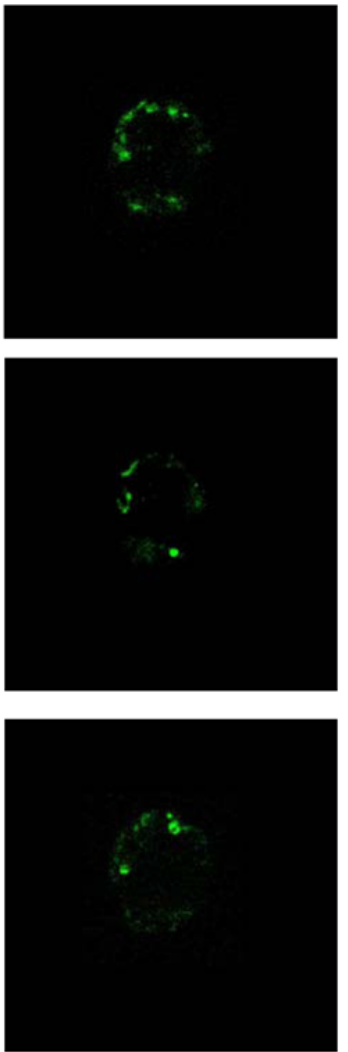

Fig. 8

TT proteolysis by U937 in the presence or absence of C3b. ${ }^{125} \mathrm{I}-\mathrm{TT}(100 \mu \mathrm{g})$ was internalised by U937 $\left(10 \times 10^{6}\right.$ cells $)$ at $37^{\circ} \mathrm{C}$ for the indicated times in the presence or not of $\mathrm{C} 3 \mathrm{~b}(100 \mu \mathrm{g})$. After cell disruption, samples were treated as described in Materials and Methods and analysed by SDS-PAGE. Residual intact TT was quantified after 20, 40 and 60min incubation as described in Materials and Methods. Results are given as means \pm SD from at least three separate experiments.

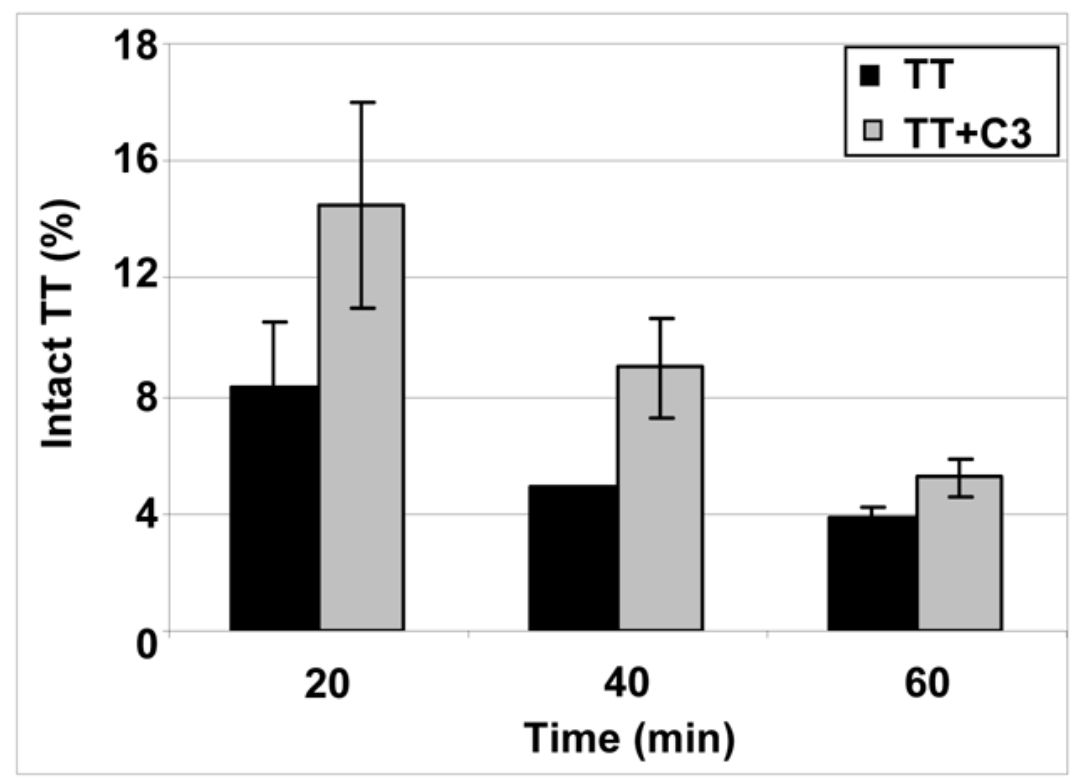

